Journal of the Bangladesh Association of Young Researchers (JBAYR): Volume 1, Number 2, June 2011, Page: 72-77, ISSN 1991-0746 (Print), ISSN 2220-119X (Online). DOI 10.3329/jbayr.v1i2.10033

Published by: BAYR

\title{
YOUTH VISION ON DEVELOPMENT THROUGH EFFECTIVE AID: BANGLADESH PERSPECTIVE
}

\author{
Mustafa Murshed \\ Bangladesh Civil Service Administration Academy \\ E-mail: mustafa murshed@yahoo.com
}

\section{INTRODUCTION}

In the era of globalization and in the presence of large-scale cross border inter-linkages the aid or external resource is a bridge to maintain the relationships among the economic entities. Foreign aid helps countries to come together in terms of humanitarian, commercial, strategic or political point of interests (Todaro, 1991, pp. 485-86). It has been the spotlight of huge number of research in recent years that how aid is contributing in the socio-economic development (Quibria, 1980). Bangladesh, a Least Developed Country (LDC), significantly depends on aid due to its resources constraint and also for establishing diplomatic relations with other countries as well as with the international agencies.

This paper focuses on the youth vision of aid effectiveness which is no doubt a relevant issue for the development thinkers because youth are the future decision makers of a country. In this essay arguments are being made to exemplify to represent the youth's view in terms of sustainable development. This essay illustrates the aid inflow in Bangladesh since December 1971 considering the possible expectations of a young citizen of the country. The analysis has been made on the basis of purpose, donors' category, debt obligation, aid requirement and utilization, etc.

\section{DEFINITIONS AND BACKGROUND}

In a broader sense, foreign aid refers to the official transfer of resources from one country to another (Todaro, 1991, pp. 481-82). It denotes the external loans given on concessional terms and grants \{Economic Relations Division (ERD), Government of Bangladesh (GoB), 2011, p. xx\}. In most of the reports, aid refers to the Official Development Assistant (ODA). According to the Development Assistant 
Committee (DAC) of Organization for Economic Co-operation and Development (OECD), aid has three criteria, these are:

i) It should be received by official or government agencies,

ii) The purpose of aid should based on economic development, and

iii) The grant element should not less than $25 \%$ of the total amount.

(Cassen, et al., 1986, p. 2)

The purpose of foreign aid is to ensure an incentive for the recipient country in order to achieve a satisfactory and self-sustaining rate of growth (Riddell, 1987, p. 107).

A great number of studies deal with the prominent Two-gap Model1. Taking the two-gap model under consideration Chenery and Strout (1966) established a positive relationship between aid and growth. Boone (1996) illustrated the importance of aid in terms of increasing the consumption rather than investment. Generally, aid in micro level creates some positive benefits whereas macro result produces different outcomes which may be positive, negative or even non-existence (Moreita, 2003).

Several studies found a positive impact of aid on the country's socio-economic and political development provided that the country follows some conditions. One of the significant research outcomes is explored by Burnside and Dollar (2000) which argued for 'good' policy to ensure the aid effectiveness. On the contrary, Hansen and Trap (2000) came with the proposition that aid increases the growth rate unconditional to 'good' policy. But the effectiveness of aid depends on the human capital and investment.

\section{Analysis and Discussion Regarding Youth Vision on Effective Aid and Development}

The main contribution of this paper is to establish a lucid picture of the vision of youth for the overall socio-economic development through effective use of aid. The role of youth can be classified into two categories;

a) Assessment of aid on the basis of debt obligation, amount received by the debtor country as well as the negotiation techniques, aid utilization, etc. and

b) What is the expectation of a youth for sustainable development?

\section{Assessment of Aid from a Youth's point of View}

In Bangladesh there always exists a gap between the commitment of the donors and the disbursed amount of aid. The global aid inflow in recent times has been declined. The rich countries are abide by an obligation to contribute $0.7 \%$ but the recent data show that it is around $0.2 \%$ to $0.4 \%$ which is resulting a shortage of about $\$ 150$ billion each year (Shah, 2011).

1 Two gaps are i) Savings-investment gap and ii) Export-Import Gap 
Table-1: Total amount of aid inflow in Bangladesh

(Million US \$)

\begin{tabular}{|c|c|c|}
\hline Time Period & Commitment & Disbursement \\
\hline Dec 1971 - June 2010 & 64461.416 & $52597.437(81.60 \%)$ \\
\hline
\end{tabular}

Source: Flow of External Resources into Bangladesh, ERD, Ministry of Finance 2011.

Generally, three sorts of aid are obtained from the external resources, these are: food, commodity and project aid (ERD, GoB, 2011, p. xxiv). Bangladesh requires a huge amount of food grains to meet the demand of the people and to run a successful safety-net programme (e.g. VGD, VGF Programmes) throughout the country (ERD, GoB, 2011, p. XXIV). Commodity Aid has been used greatly since the independence of Bangladesh to meet the trade deficit and to generate the local currency for development activities (ERD, GoB, 2011, p. xxiv). The lion's share of the total aid is the project aid, which is undertaken for financing the development projects under the Annual Development Programme (ERD, $\mathrm{GoB}, 2011$, p. xxv). In this regard, the voice of youth can be a strong platform for the country to ensure efficient aid utilization. There are two possible areas where youth can raise their voice.

The amount of bilateral aid has a downward trend in recent times which allows more aid conditionalities because it is easy to deal with one donor rather than a group of donors. The following table shows that the percentages of the bilateral and multilateral aids are just reversed in the two equal time spans.

Table-2: Classification of disbursed amount on the basis of donors' category

\begin{tabular}{|c|c|c|c|}
\hline \multicolumn{2}{|c|}{ (Million US \$) } \\
\hline Time Period & Bilateral Donor(s) & Multilateral Donor(s) & Total Amount \\
\hline July 1972- June & 13697.3 & 8491.4 & 22188.7 \\
1991 & $(61.73 \%)$ & $(38.27 \%)$ & $(100 \%)$ \\
\hline July 1991- June & 11833.8 & 18303.7 & 30137.5 \\
2010 & $(39.27 \%)$ & $(60.73 \%)$ & $(100 \%)$ \\
\hline
\end{tabular}

Source: Flow of External Resources into Bangladesh, ERD, Ministry of Finance 2011.

i) The same result found in case of the degree of concessionality i.e. how much benefit Bangladesh earned from the grant element. The table- 4 exhibits that grant element has a reducing trend which has a negative impact on debt obligation. 
Table-3: Composition of disbursed amount on the basis of recipient's degree of benefit

(Million US \$)

\begin{tabular}{|c|c|c|c|}
\hline Time Period & Grant & Loan & Total Amount \\
\hline July 1972 - June & 10687.5 & 11501.2 & 22188.7 \\
1991 & $(49.1 \%)$ & $(50.1 \%)$ & $(100 \%)$ \\
\hline July 1991- June & 11669.4 & 18486.1 & 30137.5 \\
2010 & $(38.72 \%)$ & $(61.28 \%)$ & $(100 \%)$ \\
\hline
\end{tabular}

Source: Flow of External Resources into Bangladesh, ERD, Ministry of Finance 2011

The role of youth in this circumstance may be a vital tool for the country's future development. One of the quick assessments for the measurement of aid burden can be analysed by the per capita debt obligation.

The table- 4 depicts that the economy is growing at a higher rate than the dependency rate on external resources which allows Bangladesh to be a 'less indebted' country. Because the percentage increase in GDP and the percentage increase in debt burden from June 1991 to June 2010 are 145.47 and 39.80 respectively. Using recent data the World Bank also produces similar result mentioning that Bangladesh is now a less indebted country (ERD, GoB, 2011, p. xxvii).

Table-4: Debt obligation by the citizens' of Bangladesh

\begin{tabular}{|c|c|c|c|c|}
\hline $\begin{array}{c}\text { Time } \\
\text { Period }\end{array}$ & $\begin{array}{c}\text { Per Capita Debt } \\
\text { (US \$) }\end{array}$ & $\begin{array}{c}\text { Per Capita GDP at } \\
\text { Current Price (US \$) }\end{array}$ & $\begin{array}{c}\text { \% Increase in } \\
\text { Debt Burden }\end{array}$ & $\begin{array}{c}\text { \% Increase in Per } \\
\text { Capita GDP }\end{array}$ \\
\hline \begin{tabular}{c|c|c|} 
End of June \\
1991
\end{tabular} & 105.00 & $\begin{array}{c}279.05 \\
(37.6)\end{array}$ & \multirow{2}{*}{39.80} \\
\hline End of June & 146.80 & 685.00 & \\
2010 & & $(21.43)$ & \\
\hline
\end{tabular}

N.B: The figure within the parenthesis shows the percentage of the per capita GDP Source: Flow of External Resources into Bangladesh ERD, Ministry of Finance, 2011.

Table-5 shows the percentage of foreign resources in the Annual Development Programme (ADP) of Bangladesh which states that almost 50\% resources are collected from foreign sources. There lies great room for the youth to dedicate them to build awareness regarding the domestic resources mobilization. 
Table-5: Contribution of foreign \& domestic source in ADP

(Crore Tk.)

\begin{tabular}{|c|c|c|c|c|c|c|c|c|c|c|c|}
\hline & $\begin{array}{c}2000- \\
01\end{array}$ & $\begin{array}{c}2001- \\
02\end{array}$ & $\begin{array}{l}2002- \\
03\end{array}$ & $\begin{array}{l}2003- \\
04\end{array}$ & $\begin{array}{l}2004- \\
05\end{array}$ & $\begin{array}{l}2005- \\
06\end{array}$ & $\begin{array}{l}2006- \\
07\end{array}$ & $\begin{array}{c}2007- \\
08\end{array}$ & $\begin{array}{l}2008- \\
09\end{array}$ & $\begin{array}{c}2009 \\
-10\end{array}$ \\
\hline ADP & 1820 & 1600 & 1710 & 1900 & 2050 & 2150 & 2160 & 2250 & 2300 & 2850 \\
0 & 0 & 0 & 0 & 0 & 0 & 0 & 0 & 0 & 0 \\
\hline $\begin{array}{c}\text { Foreign } \\
\text { Source }\end{array}$ & 8670 & 8215 & 8241 & 9410 & 1043 & 1070 & 1131 & 1443 & 1299 & 1636 \\
\hline $\begin{array}{c}\text { \% of } \\
\text { Foreign } \\
\text { Resourc } \\
\text { e }\end{array}$ & 47.64 & 51.34 & 48.19 & 49.53 & 50.88 & 49.77 & 43.53 & 62.56 & 44.35 & 53.66 \\
\hline
\end{tabular}

Source: (1) Bangladesh Economic Review, 2007, 2008, 2009.(2) Annual Development Programme, 200708 and 2009-10.

\section{Expectation of a Youth}

Since youth will lead the country, they must be well aware of the aid utilization and its correlation to the development. The focus of the contribution of youth has the following dimensions:

i) Aid negotiation should be favourable for the recipient country, for instance more grant element and more bilateral donors,

ii) The amount of aid is good enough for the development,

iii) The amount received from external sources has been properly utilized and no misuse,

iv) In the long run the dependency on aid has been at minimal level.

This essay found that in recent times the aid architecture has been changed which is by and large dominated by the donors. As a conscious citizen of the country, youth can make the government accountable to ensure the sovereignty of the Republic. On the other hand they can act as a pressure group so that government doesn't allow any unrealistic project in connection to the priority of the country.

Similarly, the grant element is reducing (Table-3) which has a direct negative on debt obligation. So it is the duty of the generation to stand together for construction of a platform. As mentioned earlier, aid utilization is a political success and being the future leader of the country they can introduce some political movement in favour of appropriate utilization of aid. They can bring the people interested in regard to the negotiation made by the government. To reduce the aid dependency they can encourage 
people to mobilize domestic resources. Last but not the least, they youth should ensure the proper use of aid which is not the burden of the government rather the burden of the citizens.

\section{CONCLUSION}

Aid is an inevitable part of Bangladesh economy due to the resource constraint. To meet the annual development programme as well as to fill the trade and investment deficit Government of Bangladesh is a permanent borrower in the world economy. The favourable the negotiation for the recipient country the more the financial benefits is. But the aid inflow in Bangladesh is mostly donor-driven; there is nothing left for the recipient country. At the passage of time the aid architecture is changing. To avoid this external coercive force which is mostly unfavourable, youth can actively take part in generating public opinions regarding the proper utilization of aid, in mobilizing domestic resources to reduce dependency and in ensuring a favourable negotiation so that the recipient country can achieve the highest benefit.

\section{REFERENCES}

Boone, P. (1996), "Politics Effectiveness of Foreign Aid", European Economic Review, vol. 40(2), pp.289 329.

Burnside, C. and Dollar, D. (2000), "Aid, Policies, and Growth", American Economic Review, vol. 90(4), pp. 847-68.

Cassen, R. and Associates (1986), Does Aid Work?, Oxford: Oxford University Press.

Chenery, H. B. and Strout, A. (1966), "Foreign Assistance and Economic Development", American Economic Review, vol. 56 (4), pp. 679-733.

Economic Relations Division (2011), Flow of External Resources into Bangladesh, Ministry of Finance, Government of the Peoples Republic Bangladesh, March 2011.

Hansen, H. and Tarp, F. (2001), "Aid and Growth Regressions", Journal of Development Economics, vol. 64(2), pp. 547-570.

Moreira, S. B. (2003), "Evaluating the Impact of Foreign Aid on Economic Growth: A Cross-Country Study (1970-1998)", Paper presented at the 15th Annual Meeting on Socio-Economics, Aix-enProvence, France, June $26-28,2003$.

Quibria, M. G. (1980), "Two-Gap Models of Foreign Aid: A Survey", Journal of Economic Development, vol. 5, (1), pp. 67-89.

Riddell, R. C. (1987), Foreign Aid Reconsidered, Baltimore: The Johns Hopkins University Press.

Shah, A (2011), "Foreign Aid for Development Assistance", Global Issues [online], Available at <http://www.globalissues.org/article/35/foreign-aid-development-assistance>, Accessed on July 02, 2011.

Todaro, M. P. (1991), Economic Development of the Third World, 4th Edition, Hyderabad, India: Oriental Longman Limited.

. 